\title{
IDEALISMUS FICHTOVA RANÉHO VĚDOSLOVÍ
}

\section{Lukáš Kollert}

\section{Úvod}

Fichtovu filosofii je nesnadné pochopit a snadné nepochopit. ${ }^{1}$ Důvod této skutečnosti tkví nejen v dialektické formě vědosloví dobře známé ze Základu, ale také v tom, že Fichtova vyjádření k řadě stěžejních témat a konceptů působí bez hlubší interpretace ambivalentně, nebo dokonce rozporně. Právě řečené platí kromě dalších termínů nap̌r. pro pojem věci o sobě, ale také ve vztahu k problematice realismu a idealismu. Zatímco někde Fichte vystupuje jako horlivý zastánce idealismu a zapřisáhlý odpůrce realismu a věci o sobě, na jiných místech explicitně činí věc o sobě integrální součástí své filosofie a vědosloví neváhá označit za realistické.

Právě tento problém tvoří jeden z podnětů pro sepsání předkládaného článku, jehož hlavním cílem je předložit komplexní a robustní interpretaci idealismu raného vědosloví založenou na zevrubné analýze klíčových konceptů Fichtovy filosofie a rozboru relevantních aspektů jeho metody, jež jsou zásadní mimo jiné pro pochopení ontologického statusu čin-

1 V této studii budeme pomocí zkratek odkazovat k následujícím vydáním Fichtových spisů: $G A=$ E. Fuchs - H. Gliwitzky - R. Lauth aj. (vyd.), J. G. Fichte. Gesamtausgabe der Bayerischen Akademie der Wissenschaften, Stuttgart-Bad Cannstatt 1962 nn. (odkazovat budeme na řadu, knihu a stranu); $F W=$ I. H. Fichte (vyd.), Fichtes Werke, Berlin 1971 (odkazovat budeme na knihu a stránku). Současně budeme prostřednictvím zkratek uvádět informaci o textu, k němuž odkazujeme: $E E=$ Erste Einleitung in die Wissenschaftslehre; GN=Grundlage des Naturrechts nach Prinzipien der Wissenschaftslehre; Platner = Fichtes Aufzeichnungen zu Platners Aphorismen; Recension = Recension des Aenesidemus; SB = Sonnenklarer Bericht an das größere Publikum über das eigentliche Wesen der neuesten Philosophie; $S L=$ Das System der Sittenlehre nach den Prinzipien der Wissenschaftslehre; Vergleichung = Vergleichung des von Herrn Prof. Schmid aufgestellten Systems mit der Wissenschaftslehre; Vorlesungen = Vorlesungen über Logik und Metaphysik; WLnmK $=$ Wissenschaftslehre nova methodo. Kollegnachschrift K. Chr. Fr. Krause 1798/99. Pokud existuje český překlad, budeme odkazovat na stránku českého překladu: $D U ́$ = Druhý úvod do vědosloví, in: J. G. Fichte, O pojmu vědosloví, Druhý úvod do vědosloví, Pokus o nové podání vědosloví, přel. J. Karásek, Praha 2008; $Z V V=$ Základ všeho vědosloví, přel. R. Zika, Praha 2007. 
ností transcendentálního Já. Jakkoli jsou v následující studii na základě výkladu známých, méně známých i takřkka neznámých Fichtových děl předložena také některá nesamozřejmá dílčí tvrzení, kupř. v části věnované metodě, přínosná je především jako celek a ve způsobu, jímž jsou v ní navzájem propojeny různé doktrinální elementy Fichtova myšlení.

Při sledování stanoveného cíle se nebudeme opírat pouze o gramatickou, logickou a systematickou analýzu Fichtových textů, ale také o stručně načrtnutý filosofický kontext, v němž Fichte své myšlenky artikuloval. Z tohoto hlediska jsou klíčové především Kantovo mnohoznačné pojetí věci o sobě a její kritika v dílech Kantových současníků, jež nepochybně představovaly jeden ze silných motivů pro Fichta i další vývoj tzv. „,německé klasické filosofie“.

Co do struktury je článek rozčleněn do úvodu a čtyř dalších částí. V první z nich budeme zkoumat některé z hlavních pohnutek, které Fichta vedly k formulování idealismu specifického pro vědosloví, ve druhé stručně představíme některé vybrané interpretace idealismu vědosloví, jejichž neadekvátnost se stane dostatečně zřejmou v dalších částech textu, a ve třetí se zaměříme na formu Fichtova kritického transcendentálního idealismu a v této souvislosti budeme věnovat pozornost také některým aspektům jeho metody. V poslední části článku se pak zaměříme na problematiku realismu a idealismu ve vědosloví a Fichtův vlastní „realidealismus“ nebo ,idealrealismus“ stejně jako na pojmy, jež jsou pro pochopení této pozice klíčové, konkrétně na koncepty nárazu a věci o sobě.

\section{Kantova věc o sobě a její kritika}

Podle Kanta vzniká zkušenost syntézou rozmanitosti dané ve smyslovém názoru $\mathrm{v}$ transcendentální jednotě apercepce podle kategorií jakožto čistých pojmů rozvažování. Zatímco matérie zkušenosti je dána afekcí smyslovosti věcí o sobě, která v nás vyvolává počitky, formální stránka předmětů má pramen v subjektu a tvoří transcendentální podmínku možnosti zkušenosti, at' již jde o čas a prostor coby formy smyslového názoru, kategorie nebo zásady čistého rozvažování (stranou nechávám problematiku anticipace vjemu). Matérie zkušenosti tedy nemá původ ve spontaneitě rozvažování, nýbrž v receptivitě mysli neboli schopnosti pasivně přijímat představy. Explanační role věcí o sobě v Kantově teorii poznání tak stručně řečeno spočívá v tom, že je skrze ně vysvětlena danost nahodilé rozmanitosti zkušenosti. Pokud jde o otázku určení vztahu 
mezi subjektem a věcmi o sobě, naznačuje řada míst Kritiky čistého rozumu, že Kant př́tomnost počitku chápe jako důsledek kauzálního působení věci o sobě na subjekt.

Protože však Kant v transcendentální dedukci dokazuje, že kategorie můžeme s nárokem na poznání aplikovat pouze v oboru (předmětů) možné zkušenosti, a protože věc o sobě leží mimo tuto oblast, nelze ji označit za možný předmět našeho poznání. Kant je proto, jak se zdá, zavázán $\mathrm{k}$ tvrzení, že 1) věci o sobě existují a nelze bez nich vysvětlit naši zkušenost, avšak 2) nemůžeme o nich mít žádné poznatky. Tento výklad v zásadě odpovídá klasickému čtení Kanta, podle něhož Kant zastává 1) epistemologický idealismus (naše poznání je omezeno pouze na oblast jevů), 2) ontologický dualismus (kromě myslí a představ existují také extramentální věci nezávislé co do své existence na subjektu).

Nutno však říci, že Kantův pojem věci o sobě je ambivalentní a dodnes tvoří jablko sváru kantovského bádání. Jakkoli klasické čtení dodnes představuje legitimní interpretační př́stup, ${ }^{2}$ bylo ve 20 . století podrobeno kritice, kterou předložili zejména zastánci tzv. dvouaspektové interpretace věci o sobě. Ta stručně řečeno tvrdí, že rozlišení jevů a věcí o sobě nesmíme chápat jako ontologickou, nýbrž epistemologickou distinkci, která se zakládá na dvou různých perspektivách, z nichž můžeme pohlížet na předměty zkušenosti. ${ }^{3}$ Tento pohled na věc o sobě, s nímž se setkáváme i v Heideggerově interpretaci Kanta, ${ }^{4}$ je Fichtovu smýšlení nepochybně bližší.

Pro naše zkoumání je nicméně důležitější diskuse, která byla o věci o sobě vedena na konci 18. století. Jednu z prvních kritik afekce věcí o sobě, jež měla dalekosáhlé důsledky, předložil F. H. Jacobi. ${ }^{5}$ Tento filosof ovšem ve své kritice rozhodně nebyl osamocen. Pojem věci o sobě

2 Srv. T. Rockmore, Fichte, German Idealism and the Thing in Itself, in: D. Breazeale - T. Rockmore (vyd.), Fichte, German Idealism, and Early Romanticism, Amsterdam - New York 2010, str. 15.

$3 \mathrm{~K}$ zastáncům této interpretace patří H. Allison, O. Höffe nebo G. Prauss. Srv. H. Allison, Kant's Transcendental Idealism. An Interpretation and Defense, London 1983; O. Höffe, Immanuel Kant, München 20077; G. Prauss, Kant und das Problem der Dinge an sich, Bonn 1974.

4 Srv. M. Heidegger, Fenomenologická interpretace Kantovy Kritiky čistého rozumu, přel. J. Kuneš, Praha 2004, str. 88-92.

5 F. H. Jacobi, David Hume über den Glauben, oder Idealismus und Realismus, Breslau 1787, str. 209 nn. 
se stal terčem útoku také ze strany dalších významných Kantových současníků, z nichž nelze nezmínit alespoň Maimona nebo Schulzeho. ${ }^{6}$

Jacobi si ve své kritice počíná tak, že proti sobě staví jednotlivá Kantova tvrzení a snaží se prokázat jejich vzájemnou neslučitelnost. Kant podle Jacobiho tvrdí, že subjekt je afikován kauzálním pưsobením věcí o sobě - o nichž Kant nezřídka hovoří jako o předmětech - a že v něm věci tímto působením vyvolávají představy. Tato teze je nicméně podle Jacobiho názoru v rozporu s jinými doktrinálními prvky Kantovy filosofie. Jacobi tvrdí:

1) Pokud předměty nejsou nic než pouhé jevy, které jsou formovány subjektem a jsou jeho určeními, nemohou být současně věcmi, jež jsou na něm nezávislé a vytvářejí v nás predstavy.

2) Teze o kauzální afekci věcmi o sobě znamená nelegitimní aplikaci kategorií mimo obor (předmětů) možné zkušenosti. Je nadto v rozporu s obecnou tezí, že věci o sobě jsou nepoznatelné. Jakkoli můžeme o předmětech legitimně tvrdit, že působí na naše smysly, platí to pouze pro předměty spadající do oblasti empirické reality, a nikoli mimo ni.

Po představení a rozvedení těchto rozporů vynáší Jacobi nad Kantovým transcendentálním idealismem verdikt, který se stal slavným a na současníky hluboce zapůsobil. O předpokladu věci o sobě ř́íká:

„bez tohoto předpokladu jsem nemohl do systému vstoupit a $s$ tímto předpokladem jsem v něm nemohl setrvat."

Na závěr své kritiky pak chce neudržitelnost transcendentálního idealismu dokázat tím, že přívržence tohoto filosofického stanoviska staví před dvě alternativy, z nichž obě jsou podle jeho soudu neakceptovatelné.

6 S. Maimon, Versuch über die Transcendentalphilosophie mit einem Anhang über die symbolische Erkenntniß und Anmerkungen, Berlin 1790, str. 415; G. E. Schulze, Aenesidemus oder über die Fundamente der von dem Herrn Professor Reinhold in Jena gelieferten Elementar-Philosophie, Hamburg 1996 [1792], str. 263 n. K diskusi o věci o sobě a jejímu vývoji od Maimona, Becka a Tieftrunka k Fichtovi srv. J. Karásek, Věci o sobě a jevy. Zrod německého idealismu v dopisech Kantových žáků, in: M. Znoj (vyd.), Hegelovskou stopou. K poctě Milana Sobotky, Praha 2003, str. 17-37.

7 F. H. Jacobi, David Hume über den Glauben, str. 223. Přeložil L. K. 
Idealista bud’to může lpět na svém současném postoji a připustit nezbytnost realistických elementů, avšak v tom př́ípadě je inkonsistentní, nebo

„musí mít odvahu zastávat nejráznější idealismus, jaký byl kdy vyučován, a nesmí se bát dokonce ani obvinění ze spekulativního egoismu, nebot' ve svém systému by nemohl setrvat, pokud by se chtěl tohoto posledního obvinění zbavit.“8

Tím, kdo se chopil této provokativní výzvy a pokusil se nově formulovat transcendentální idealismus tak, aby jej obhájil před námitkami Jacobiho i dalších myslitelů, pak nebyl nikdo jiný než autor vědosloví.

\section{Nepochopení Fichtova idealismu}

Fichte si Jacobiho kritiky považoval a ztotožňoval se s ní, jak je patrné z Druhého úvodu, ${ }^{9}$ avšak vyvodil z ní jiné důsledky. I když Jacobiho výzva společně s Aenesidemem nepochybně představovala jeden z klíčových podnětů pro vypracování vědosloví, ${ }^{10}$ nevedla Fichta ani ke spekulativnímu egoismu neboli solipsismu, ani k ontologickému idealistickému monismu. Můžeme sice říci, že Fichte předkládá „,nejráznější idealismus“, avšak v jiném smyslu než v tom dvojím, který jsme právě uvedli. Podstatu tohoto idealismu se pokusíme v následujících částech studie postupně předvést. Začneme tím, že představíme některé z pozic, které Fichte nezastával, ač byly s jeho jménem spojovány.

Hned na úvod je třeba zdůraznit, že idealismus je podobně jako realismus širokým a mnohoznačným pojmem. Kromě mnoha jiných distinkcí můžeme provést rozlišení např. mezi idealismem jako epistemologickou a ontologickou pozicí a zkoumat jejich vztahy. Pokud budeme bez dalšího konstatovat, že Fichte byl idealista, nedozvíme se o jeho filosofii prakticky nic. Klíčová je otázka, jakou formu idealismu Fichte zastával.

Interpreti německé pokantovské filosofie měli na tuto otázku dlouho jasnou a poměrně prostou odpověd'. Fichte pod dojmem Jacobiho kritiky a výzvy odmítl Kantovu věc o sobě a formuloval onen „nejráznější idealismus“, jenž nemohl spočívat v ničem jiném než v odmítnutí

8 Tamt., str. 229. Přeložil L. K.

9 Srv. J. G. Fichte, $D U ́$, str. 80 n.

10 K vlivu Aenesidema viz dopisy a náčrty dopisů Flattovi, Niethammerovi, Stephanimu a Wloemarovi z roku 1793 a Reinhardovi z roku 1794. 
existence extramentální reality a v lokalizování veškeré skutečnosti do absolutního Já. Toto nepochopení je staré jako vědosloví samo, nebot' se objevilo takřka současně s prvním vydáním Základu, jehož úvodní pasáže $\mathrm{k}$ této interpretaci svádí a vedou čtenáře $\mathrm{k}$ domněnce, že Fichte předkládá ontologický idealistický monismus. ${ }^{11}$ Jakkoli má tento výklad určitou logiku a může se oprrít o nemálo Fichtových tvrzení, jsou-li tato tvrzení uvážena izolovaně, podává uvedený výklad celkově vzato naprosto zkreslený obraz vědosloví. Seznam autorů, kteří Fichta pochopili jako teoretika absolutního, deizovaného Já, jež coby původní metafyzický pramen skutečnosti produkuje veškerou realitu, rozhodně není krátký. Již Fichtův posluchač Hölderlin chápe absolutní Já v duchu Spinozovy substance jako souhrn veškeré reality v silném slova smyslu, mimo nějž nic dalšího neexistuje. ${ }^{12}$ Josiah Royce, významný americký idealista přelomu 19. a 20. století, zase Fichtovi podsouvá stanovisko, že z předvědomé činnosti Já mají být odvozeny nahodilé obsahy zkušenosti, když mu např. klade otázku, proč vytváŕíme svět, v němž se mezi orbitami Marsu a Jupitera nachází pás asteroidů apod. ${ }^{13}$ Bertrand Russell o další řadu let později píše, že ,podle Fichta je vše pouhou emanací Já“ a že filosofie od předložení této „š́lené“ teze začala hledat cestu zpět ke zdravému rozumu. ${ }^{14}$ Podle těchto a mnoha dalších interpretů Fichte opustil rámec kritické epistemologie a vydal se na cestu bezbřehé spekulativní metafyziky, kterou se Kant snažil odmítnout.

Pokud by vědosloví skutečně bylo filosofií ontologického idealistického monismu nebo případně solipsismu, bylo by stěží něčím více než jednou z kuriózních pozic v panoptiku podivuhodných filosofií, jež sice mohou být zajímavé, a $\mathrm{v}$ jednotlivostech dokonce inspirativní, nicméně celkově jsou určeny spíše k odmítnutí. Chceme-li však náležitě porozumět idealismu Fichtova vědosloví, musíme si v první řadě zachovat odstup právě od těchto tradovaných schematických představ a karikatur, které zůstávají dosud zakořeněny v širším povědomí mimo okruh specializovaného fichtovského bádání.

11 Stranou nechávám výše zmíněný scestný výklad, podle něhož je vědosloví solipsistické.

12 Srv. Hölderlinův dopis Hegelovi z 26. 1. 1795. Srv. dále V. L. Waibel, Hölderlin und Fichte. 1794-1800, Paderborn - München - Wien - Zürich 2000, str. 27 nn.

13 Srv. J. Royce, The Spirit of Modern Philosophy. An Essay in the Form of Lectures, Boston - New York 1892, str. 167.

14 B. Russell, A History of Western Philosophy, London 1946, str. 18. 
Pro úplnost nutno dodat, že př́íčinu pro dlouhé dějiny neporozumění vědosloví zavdal do značné míry sám Fichte. Kámen úrazu spočíval již ve skutečnosti, že první vědosloví vydal nadvakrát. V roce 1794 publikoval první dva díly a až v roce 1795 díl třetí, který staví mnohé teze prvních dvou částí do poněkud odlišného světla. Další problém jsme naznačili již v úvodu práce: Fichte předkládá mnoho ne zcela št’astně formulovaných výroků, jež k zavádějícím výkladům svádějí, pokud nejsou uváženy v kontextu vědosloví jako celku a s přihlédnutím k úvahám o metodě vědosloví. Fichte sám si byl nedostatečností svého opus magnum vědom a do konce života usilovně pracoval na novém podání vědosloví. V dopisech Reinholdovi dokonce připouští, že jeho schopnost vhledu je u něj negativně vyvážena nedostatkem schopnosti přesného vyjádření a že zřejmě není schopen vcítit se do myšlení čtenářů, a proto chybně předpokládá mnohé za samozřejmé. ${ }^{15}$

\section{Metoda vědosloví a status činností transcendentálního Já}

Naši snahu přiblížit povahu a metodu Fichtova idealismu započneme tím, že obrátíme pozornost k Fichtovu rozlišení mezi stanoviskem života a stanoviskem spekulace. První stanovisko označuje postoj běžného přirozeného vědomí, které je jakožto prakticky jednající vždy již vrženo do světa a zakouši předměty jako na sobě nezávislé. Toto vědomí, jež je v každodenním životě nutně vlastní také idealistickému filosofovi, zastává z epistemologického hlediska pozici naivního realismu či dogmatismu a můžeme je charakterizovat jako prímé, nereflektované bytí u objektů. ${ }^{16}$ Podle Fichta je pro toto vědomí příznačné, že zapomíná na sebe sama a činnosti, skrze něž dochází ke konstituci předmětů a jejich vědomí, a proto svět nutně zakouší jako na sobě nezávislý celek smyslu. ${ }^{17}$

Spekulace je naopak umělým postojem filosofa, k němuž se člověk pozvedá aktem svobody, když chce reflektovat přirozené vědomí a snaží se odhalit nebo lépe řečeno (re)konstruovat skrytou vnitřní zákonitost jeho fungování. Filosof na tomto stanovisku vykračuje nad zkušenost a táže se po jejích důvodech. Jeho úkolem je explikovat a geneticky zná-

\footnotetext{
15 Srv. dopisy Reinholdovi z 21. 3. 1797 a 22. 4. 1799.

16 Srv. J. G. Fichte, Vorlesungen (GA IV,1, str. 212 n.).

17 Srv. J. G. Fichte, $S L$ (FW IV, str. 31); $W \operatorname{LnmK}(G A$ IV,2, str. 29).
} 
zornit zkušenost přirozeného vědomí neboli systém představ doprovázených pocitem nutnosti, včetně přesvědčení, že existují věci nezávislé na vědomí. ${ }^{18}$ Vědosloví má objasnit konstituci našeho vědomí nezávislého světa nebo přesněji řečeno vědomí světa, jenž je ve vědomí vědom jako na vědomí nezávislý, přestože je produktem činnosti Já. ${ }^{19}$ Nemá přitom za cíl přesvědčení přirozeného vědomí o nezávislosti světa demaskovat jako pomýlené a stanovisko života nahradit, nýbrž odhalit transcendentální činnosti Já, na jejichž základě nutně vzniká, a touto cestou je filosoficky odůvodnit. Stejně tak není jeho cílem ukázat, jak absolutní Já na způsob božské kreace skrze absolutní kauzalitu tvoří svět, nýbrž jak vzniká naše vědomí světa jako nezávislého na Já.

Jakkoli vědoslovec na rozdíl od přirozeného vědomí odmítá pozitivně tvrdit, že existuje svět zcela nezávislý na Já, nejsou tato dvě stanoviska podle Fichta ve skutečnosti v rozporu, nebot' se nacházejí na odlišných rovinách myšlení. ${ }^{20}$ Zatímco přirozené vědomí je „způsobem myšlení“, vědosloví je spekulací a reflexí tohoto vědomí.

Na základě řečeného můžeme konstatovat, že zkušenost tvoří v různých ohledech východisko i cíl vědosloví. Motivem vedoucím ke spekulaci je podle Fichta v lidském rozumu zakořeněná potřeba si zkušenost vysvětlit. ${ }^{21}$ Nereflektovanou zkušenost sice lze označit za bezprostředně jistou, nikoli však pochopenou. Cílem vědosloví je dospět ke zkušenosti, z níž se původně vychází (výsledky filosofie se musí, jak říká Fichte, shodovat se zkušeností), ${ }^{22}$ která však již nebude pouze jistá, ale také explikovaná co do podmínek své možnosti, a to pomocí systému jistých vět, jež svou jistotu čerpají z evidence principu vědosloví a komplexního metodického postupu opírajícího se o intelektuální názor ( $\mathrm{k}$ tomu viz níže). Fichte proto může v Sonnenklarer Bericht (Nad slunce jasná zpráva) směle tvrdit, že s Kantem a Jacobim sdílí přesvědčení, že veškeré naše myšlení má svůj základ i konec ve zkušenosti. ${ }^{23}$

18 Srv. J. G. Fichte, $D U ́$, str. 61.

19 Srv. J. G. Fichte, Neue Bearbeitung der Wissenschaftslehre (1800) (GA II,5, str. 366 n.); DÚ, str. 60 (pozn. č. 39); GN (FW III, str. 24); Vergleichung (FW I, str. 440); WLnmK (GA IV,2, str. 265). Srv. dále dopis Jacobimu z 30. 8. 1795, Lavaterovi ze 7. 3. 1799 a Reinholdovi z 22. 4. 1799.

20 Srv. J. G. Fichte, $W \operatorname{LnmK}(G A$ IV,2, str. 27).

21 Srv. J. G. Fichte, $E E$ ( $F W$ I, str. 446).

22 Srv. J. G. Fichte, $W \operatorname{Lnm} K(G A$ IV,2, str. 25).

23 Srv. J. G. Fichte, SB (GA I,7, str. 194). Dále srv. G. Zöller, Fichte's Transcendental Philosophy. The Original Duplicity of Intelligence and Will, Cambridge 1998, str. 21. 
Jakkoli však zkušenost tvoří východisko vědosloví co do motivu, jeho spekulativním východiskem je absolutní Já, k němuž se filosof pozvedá aktem svobodné abstrahující reflexe. ${ }^{24}$ Když provedeme abstrakci ode všeho, od čeho můžeme abstrahovat, a reflexi na to, od čeho abstrahovat nemůžeme, zjistíme podle Fichta, že naprosto nelze abstrahovat od čistého neboli absolutního Já. Nutno zdůraznit, že právě v tomto duchu je třeba vykládat Fichtovu tezi o absolutním sebekladení čistého Já. Absolutní Já je tím, co se klade naprosto, jelikož pouze od něj naprosto nemůžeme abstrahovat. Fichte sám říká, že vědosloví

„nemá žádné jiné pravidlo než: je abstrahováno ode všeho, od čeho lze abstrahovat, dokud nezůstane něco, od čeho je zcela nemožné abstrahovat. Toto zbývající je čisté Já, které je coby čisté Já právě skrze tuto nemožnost od něj abstrahovat jakožto regulativ schopnosti myslet plně určeno. Je tím, od čeho naprosto nemůžeme abstrahovat, protože je samo tím, kdo abstrahuje, nebo - což je totéž - tím, co sebe sama klade naprosto“. 25

Filosof pomocí této abstrakce a reflexe nachází evidentní větu tvořící hlavní zásadu vědosloví, od níž následně hodlá pomocí určitého postupu dospět k dalším větám, na něž bude přenesena jistota původní propozice, a vybudovat touto cestou systém filosofie tvořený soustavou jistých vět. Stanoveného cíle dosahuje předvedením toho, že původní sebekladení je možné pouze za podmínky realizace dalších aktů, které jsou samy možné pouze za podmínky dalších činností atd. ${ }^{26}$ Jistota původní činnosti je pak na ostatní jednání přenesena právě na základě této podmíněnosti. Filosof podle Fichta

„ukazuje, že to, co nejprve stanovil jako zásadu a bezprostředně vykázal ve vědomí, není možné, aniž by se současně událo ještě něco dalšího, a toto není možné, aniž by se událo něco třetího; [postupuje prritom] tak dlouho, dokud zcela nevyčerpá podmínky toho, co nejprve vykázal, a dokud není totéž zcela pochopitelné co do své možnosti. Jeho postup je tak nepřerušeným postupem od podmíněného

24 Srv. J. G. Fichte, $W \operatorname{LnmK}(G A$ IV,2, str. 19).

25 J. G. Fichte, Über den Unterschied des Geistes und des Buchstabens in der Philosophie (GA II,3, str. 329). Přeložil a kurzivou zdůraznil L. K.

26 Srv. J. G. Fichte, SL (GA I,5, str. 41). Srv. dále Ch. Binkelmann, Theorie der praktischen Freiheit: Fichte - Hegel, Berlin - New York 2007, str. 36. 
k podmínce. Podmínka je sama opět podmíněna a je třeba vyhledat její podmínku“. 27

Vědoslovec si počíná tak, že $\mathrm{v}$ dialektickém procesu identifikuje rozpor obsažený v určité větě (analytická část postupu), a hledá koncept, pomocí něhož lze tento rozpor odstranit (syntetická část postupu). Jinak řečeno, Fichte nepředkládá na počátku spekulace definice a axiomy, z nichž by pomocí logických pravidel dedukoval závěry, nýbrž předvádí $\mathrm{v}$ dialektickém pohybu různé pozice, nachází v nich rozpory a kreativně hledá nové pojmy a principy umožňující syntézu, a to tak dlouho, dokud nenalezne finální syntézu a nevysvětlí předmětné vědomí. ${ }^{28} \mathrm{~V}$ tomto procesu nepoužívá fixní algoritmus, nýbrž provádí spíše experiment, při němž je nutné zapojit obrazotvornost, kterou můžeme přibližit jako tvưrčí a kultivovatelné filosofické nadání pro řešení úloh.

Fichte v rámci popsaného procesu kromě původního sebekladení předvádí celou řadu dalších činností transcendentálního Já. Problematika abstrahující reflexe a dialektického postupu vědosloví nás nicméně přivádí k jedné z nejdůležitějších otázek fichtovského bádání, totiž otázce statusu činností, které jsou popsány větami a zásadami vědosloví. Již jsme poznamenali, že filosof se na stanovisko spekulace pozvedá abstrakcí, pomocí níž nachází evidentní bod, na němž hodlá založit vysvětlení naší zkušenosti. V odpovědi na naši otázku je třeba konstatovat, že status takto získané činnosti odpovídá způsobu, jímž filosof k představě o ní dospívá - izolované, čisté, absolutní Já je abstrakcí, kterou si utváří pouze filosof na rovině spekulace a která mu slouží k explikaci běžného předmětného vědomí. To nicméně neznamená, že se jedná o smyšlenku. Jde naopak o nutnou myšlenku filosofické reflexe zkušenosti, kterou si nutně vytváríme, když si ji ve filosofii vysvětlujeme náležitým systematickým způsobem. Jelikož je pocit nucení pro Fichta znakem reality, můžeme o sebekladení a dalších jednáních transcendentálního Já říci, že jsou reálná: nakolik jsme nuceni provádět filosofickou reflexi, natolik těmto jednáním př́ísluší realita nutných myšlenek. ${ }^{29}$ Jelikož však tato

27 J. G. Fichte, $E E$ ( $F W$ I, str. 446). Přeložil L. K. Srv. dále $W \operatorname{LnmK}(G A$ IV,2, str. 25).

28 Srv. W. Hartkopf, Die Dialektik Fichtes als Vorstufe zu Hegels Dialektik, in: Zeitschrift für philosophische Forschung, 21, 1967, str. 173-207.

29 Srv. J. G. Fichte, $G N$ ( $F W$ III, str. 24 n.); $W \operatorname{LnmK}(G A$ IV,2, str. 26). Dále srv. D. Breazeale, Die synthetische(n) Methode(n) des Philosophierens. Kantische Fragen, Fichtesche Antworten, in: J. Stolzenberg (vyd.), Kant und der Frühidealismus. System der Vernunft, Hamburg 2007, str. 81-102. 
jednání mimo filosofickou reflexi neexistují, lze popsat jejich modus bytí jako bytí pro vědomí filosofa. ${ }^{30}$ Zatímco myšlení sebe sama realizované studentem vědosloví na základě výzvy je skutečným jednáním, v němž se můžeme s jistotou přesvědčit o existenci sebe sama jako subjektu vůbec, absolutní Já je čistou formou této činnosti a základní komponentou jeho filosofického obrazu, ve kterém chceme ono jednání pojmout jakožto analyzované, vysvětlené a zdůvodněné.

Je dále třeba zdůraznit, že činnosti artikulované ve vědosloví postupně jako jednotlivá jednání jsou podle Fichta mimo filosofickou reflexi pouze jedním celkovým ,jednáním inteligence“,31 které jen filosof coby konečná bytost musí znázorňovat jako rozdělené, nebot' jinak mu není schopen porozumět. ${ }^{32}$ Fichte o těchto jednáních někdy hovoří dokonce jako o fikcích. ${ }^{33}$ Můžeme proto říci, že vědosloví není pravdivé v žádné své izolované části, nýbrž pouze jako celek. Tuto okolnost je třeba neztrácet ze zřetele ani při výkladu čistého Já a intelektuálního názoru, nebot' právě uvedené platí i pro sebekladení absolutního Já. Fichte např. tvrdí:

„živé tělo, které zpodobujeme, je běžné reelní vědomí. Postupné spojení jeho částí jsou naše dedukce, které mohou postupovat jen krok za krokem. Dokud není celý systém dokončen, je vše, co můžeme přednést, jen část.“"34

I na mnoha jiných místech se ukazuje, že vědosloví není metafyzickou teorií deizovaného absolutního Já, nýbrž konečného subjektu:

„podstata rozumu tkví v tom, že kladu sebe sama, to však nemohu učinit, aniž bych proti sobě kladl svět, a sice určitý svět, který je v prostoru a jehož jevy po sobě následují v čase. To vše se odehrává v jednom neděleném okamžiku. Jelikož se děje jedno, děje se současně vše ostatní. Filosofie nicméně chce ... tomuto jednomu aktu přesně porozumět, člověk však nemůže ničemu přesně porozumět, pokud [zkoumané] nerozloží a nerozebere. Právě tak si počíná i vědosloví s oním jedním jednáním Já. Získáváme tak řadu navzájem propoje-

\footnotetext{
30 Srv. Ch. Binkelmann, Theorie der praktischen Freiheit, str. 37.

31 Srv. J. G. Fichte, DÚ, str. 64; Vergleichung (FW I, str. 444).

32 Srv. J. G. Fichte, WLnmK (GA IV,2, str. 68).

33 Srv. J. G. Fichte, $S B$ (GA I,7, str. 249).

34 Srv. „Fragment“ tvořící prrílohu dopisu Reinholdovi z 22. 4. 1799. Přejímám překlad J. Kuneše.
} 
ných jednání Já - protože ono jednání nemůžeme pochopit naráz, nebot' filosof je bytostí, jež musí myslet v čase. “35

Představu o vědomí vytvořenou filosofickou reflexí je třeba chápat jako znázornění nebo model přirozeného vědomí s tím, že vědoslovec na systematicky předvedená jednání pohlíží tak, že se jedná o rekonstrukci původní sebekonstrukce Já, kterou provádí konečný subjekt sám. Když si ve filosofické reflexi znázorňujeme své vědomí, pohlížíme na ně, jako kdyby se jednalo o výsledek konstrukce, která se shoduje s naší umělou rekonstrukcí tohoto vědomí.

Status činností popsaných vědoslovím si můžeme ještě dále přiblížit pomocí analogie mezi vědoslovím a geometrií, kterou Fichte bohužel rozvádí jen velmi kuse a $\mathrm{v}$ méně známých spisech. ${ }^{36}$ Tato skutečnost je politováníhodná, nebot' právě analogie mezi geometrií a filosofií má z hlediska snahy pochopit metodu vědosloví značný potenciál. Filosof má podle Fichta za cíl předložit v rámci procesu (re)konstrukce, v němž se opírá o intelektuální názor, ${ }^{37}$ vysvětlení určitého předmětu, totiž skutečného vědomí, podobně jako geometr, jenž pomocí konstrukce v čistém názoru dochází $\mathrm{k}$ apriorním poznatkům o předmětech nacházejících se v prostoru, demonstruje jejich vlastnosti, vzájemné poměry atd. Podobně jako provádí geometr demonstraci vět nebo pouček pomocí konstrukcí v názoru (v nichž sjednocuje zvláštní a obecné, konečné a nekonečné, protože na jednotlivém obrazci nahlíží zákonitosti platné pro určité obrazce vủbec, nebot' od zvláštností daného obrazce odhlíží), ${ }^{38}$ provádí i filosof demonstraci na základě konstrukce v názoru, jehož předmětem nicméně nejsou prostor a jeho limitace, nýbrž rozum sám, resp. činnost. Fichte proto také vědosloví označuje jako mathésis lidského rozumu. ${ }^{39}$ Stejně jako geometr konstruuje obrazec, aby získal jeho přesnou a diferencovanou představu, konstruuje filosof předmětné vědomí, aby získal jeho akurátní, genetickou koncepci.

35 J. G. Fichte, Wissenschaftslehre nova methodo. Kollegnachschrift K. Chr. Fr. Krause 1798/99, Hamburg 1994, str. 8 n. Přeložil L. K.

36 Setkáváme se s ní v Züricher Vorlesungen, Neue Bearbeitung der Wissenschaftslehre (1800), Ankündigung. Seit sechs Jahren, v SB a ve Wissenschaftslehre 1813. Za Fichtova života byla zveřejněna pouze Nad slunce jasná zpráva. Z uvedeného je patrné, že jakkoli Fichte tuto analogii sledoval od počátku do konce úvah o vědosloví, jeho zájem o ni kulminoval kolem roku 1800.

37 Srv. J. G. Fichte, $S B$ (GA I,7, str. 233).

38 Tamt., str. 228.

39 Srv. J. G. Fichte, Ankündigung. Seit sechs Jahren (GA I,7, str. 153-164). 
Právě expozice a konstrukce v názoru je podle Fichta v př́ípadě obou věd důvodem, proč se jejich věty těši stejné jistotě, universálnosti, nutnosti a nevyvratitelnosti. Podobně jako se můžeme v geometrii na základě názoru přesvědčit o nutnosti toho, že dva body lze spojit pouze jednou prrímkou, můžeme se podle Fichta pomocí názoru přesvědčit, že určité činnosti ducha lze myslet pospolu pouze jedním určitým způsobem. Na základě názoru můžeme nahlédnout, jak si při východisku od určitých daností (znalosti velikosti úhlu apod.) musí nutně počínat každý, kdo chce sestrojit určitý obrazec, a jak si musí počínat každý, kdo chce konstruovat předmětné vědomí. Výchozím bodem spekulace filosofa je přitom absolutní Já, které odpovídá matematickému bodu, z něhož geometr vychází při konstrukci geometrického útvaru a z něhož vede přímku. Tomu odpovídá také ontologický status čistého Já stejně jako dalších jednání představených ve filosofické reflexi. Stejně jako nejsou postuláty, axiomy, body, linie nebo geometrické obrazce skutečné v tom smyslu, v němž jsou skutečné zakoušené předměty nacházející se v prostoru, nejsou ani činnosti tvořící součást filosofovy konstrukce skutečné v témže smyslu jako živoucí přirozené vědomí. Fichte $\mathrm{z}$ této okolnosti nicméně nevyvozuje závěr, že bychom linie nebo činnosti Já měli chápat jako nereálné. V krátkém textu z roku 1800 poznamenává:

„pan Heusinger se domnívá, že s vědoslovím zcela skoncoval tím, že čisté Já, z nějž systém vychází, prohlašuje za psychologický klam. Jako kdyby bylo vědosloví psychologií a vycházelo z faktů vědomí, a ne ze zcela svobodných produktů spekulace - [počíná si] právě tak, jako kdyby chtěl někdo dokázat nicotnost geometrie tím, že by prohlásil za psychologický klam matematický bod a prímku, asi proto, že si je nelze představit ve vnějším vnímání." ${ }^{0}$

S citací této dosti výmluvné pasáže můžeme uzavřít zkoumání statusu činností popsaných vědoslovím stejně jako vybraných aspektů jeho metody a přejít $\mathrm{k}$ další části této studie, $\mathrm{v}$ níž se budeme věnovat realismu a idealismu ve vědosloví.

40 Srv. J. G. Fichte, An das philosophische Publikum (GA I,6, str. 458). Přeložil L. K. Vztah mezi geometrií a vědoslovím nebyl dosud náležitě prozkoumán. Výjimku tvoří několik článků D. Breazeala a monografie D. W. Wooda, Mathesis of the Mind. A Study of Fichte's Wissenschaftslehre and Geometry, Amsterdam - New York 2012. 


\section{Realismus, idealismus a matérie našich představ}

Fichtovo předvedení protikladu mezi realismem a idealismem v raném vědosloví je na první pohled matoucí a snadno čtenáře svádí na stopu chybného výkladu. Tato skutečnost je zapříčiněna především tím, že Fichte realismus a idealismus představuje poněkud jiným způsobem v Základu na jedné straně, a spisech určených širšímu publiku na straně druhé. Např́klad Rockmore proto rozlišuje mezi Fichtovou „exoterickou“ a „esoterickou“ pozicí. ${ }^{41}$

Fichte nezřídka používá „idealismus“ jako synonymum „kritického transcendentálního idealismu“ a klade jej do zásadního protikladu vůči dogmatismu ve smyslu pozice vycházející z existence věcí o sobě. Jinde však hovoří o „dogmatickém idealismu“, a připouští tak, že také idealismus může být dogmatický. Zatímco někde idealismus a realismus prezentuje jako neslučitelné protiklady, na jiných místech klade důraz na okolnost, že vědosloví nelze chápat prostě jako „idealismus“, ale spíše jako syntézu realismu a idealismu nebo střední cestu mezi nimi, kterou označuje za „idealrealismus“ nebo „realidealismus“. ${ }^{42}$ Totéž platí i pro pojem věci o sobě. Někde je včleněna do vědosloví jako nutný pojem filosofické reflexe, avšak jinde ji Fichte zaníceně odmítá a přivádí čtenáře $\mathrm{k}$ domněnce, že ve vědosloví nemá žádné místo.

V Recenzi Fichte tvrdí:

,jak se však liší kritický systém od toho, který jsme výše označili jako humovský? Pouze v tom, že zatímco humovský systém ponechává otevřenou možnost, že budeme moci jednou vykročit za omezení lidského ducha, kritický systém prokazuje absolutní nemožnost takového postupu a ukazuje, že myšlenka věci, jíž mají př́slušet existence a jisté vlastnosti $o$ sobě a nezávisle na nějaké schopnosti představování, je podivínský nápad, přelud, nesmysl.“43

V Prvním úvodu o několik let později píše, že dogmatikův

„princip, věc o sobě, je ničím a nemá, jak musí sám zastánce dogmatismu připustit, žádnou realitu kromě té, kterou má obdržet skrze skutečnost, že se pouze z ní dá vysvětlit zkušenost. Tento důkaz od-

41 Srv. T. Rockmore, Fichte, German Idealism and the Thing in Itself, str. $15 \mathrm{nn}$.

42 Srv. J. G. Fichte, $Z V V$, str. 161.

43 J. G. Fichte, Recension (FW I, str. 17). Přeložil L. K. 
straňuje idealista tím, že zkušenost vysvětluje jiným způsobem, takže popírá právě to, na čem dogmatismus staví. Z věci o sobě se stává naprostá chiméra; ukazuje se, že neexistuje vůbec žádný důvod, proč bychom ji měli prrijmout, a společně s ní se hroutí celá budova dogmatismu." 44

S těmito radikálně odmítavými vyjádřeními kontrastuje tvrzení ze Základu publikovaného v době mezi vydáním Recenze a Prvního úvodu:

„posledním důvodem veškeré skutečnosti je tedy podle vědosloví původní, vzájemné působení mezi Já a jakýmsi Něčím mimo Já, o kterém nelze říci nic dalšího než to, že musí být zcela protikladné Já.“45

Jak jsou tyto na první pohled protichůdné výroky slučitelné? Při hledání odpovědi musíme vzít v úvahu žánr textů, v němž se nacházejí, stejně jako publikum, jemuž jsou určeny. Zatímco ve spisech pro širší (akademickou) veřejnost předkládá Fichte radikálnější tvrzení o věci o sobě, v Základu s tímto termínem pracuje jinak a činí z něj integrální součást svého projektu. Řešení identifikovaného problému zní v konečném důsledku tak, že když Fichte kritizuje věc o sobě, má na mysli spíše specifický pojem věci o sobě, především ten, s nímž operují kantiáni a dogmatikové. Jinak řečeno, Fichte kritizuje takové pojetí věci o sobě, jež nerespektuje „nutný kruh“ lidského rozumu (k tomu viz níže), a snaží se založit teorii lidského poznání včetně výkladu objektivity poznatků na konceptu věci o sobě (domněle) zcela nezávislé na Já.

Vrat'me se však k rozlišení idealismu a realismu a zaměřme pozornost na Fichtovy argumenty proti druhé pozici. Cílem obou stanovisek je podle Fichta vysvětlit naši zkušenost. Protože však musí podle jeho soudu důvod ležet mimo zdůvodněné, ${ }^{46}$ musí se obě pozice při explikaci zkušenosti postavit nad ni a vykročit na rovinu spekulace. Tento krok lze realizovat pouze skrze reflexi na zkušenost a abstrakci od jednoho ze dvou základních momentů, které v ní nacházíme jako spojené. ${ }^{47}$ Zatímco idealismus reflektuje na Já a abstrahuje od věcí, dogmatismus reflektuje

44 J. G. Fichte, $E E$ ( $F W$ I, str. 430). Přeložil a zdůraznil L. K. Na jiném místě Fichte tvrdí, že věc o sobě je ,absurdita“. Srv. $W \operatorname{Lnm} K(G A$ IV,2, str. 39).

45 J. G. Fichte, $Z V V$, str. 160.

46 Srv. J. G. Fichte, $E E$ ( $F W$ I, str. 423 n.); $W \operatorname{Lnm} K(G A$ IV,2, str. 19).

47 Srv. J. G. Fichte, WLnmK (GA IV,2, str. 20). 
na objekt a abstrahuje od Já. Východiskem idealismu je tedy čisté Já a východiskem dogmatismu abstrakcí získaná věc o sobě.

Proti pozici vycházející z věci o sobě formuluje Fichte přinejmenším čtyři základní typy argumentů. Dogmatismus za prvé musí na Já pohlížet jako na věc mezi věcmi nebo rezultát vzájemného působení mezi nimi, ${ }^{48}$ a proto nedokáže vysvětlit, jak se z určení Já může stát určení Já existující pro Já. Jinak řečeno, nedokáže objasnit, jak se může z reálného určení Já stát určení ideální. ${ }^{49} \mathrm{Za}$ druhé je třeba zmínit etickou perspektivu a argument, že dogmatismus vede k fatalismu a determinismu, zatímco vědosloví je naopak jedinou filosofií slučitelnou se svobodou. Fichte dogmatikovi za třetí namítá, že jeho předpoklad věci o sobě a s ním spjatá teorie poznání nutně vedou ke skepticismu. Zatímco argumenty skeptiků proti dogmatikům autor vědosloví vítá, zcela se s nimi rozchází, pokud jde o důsledky, jež z nich máme vyvodit. Skeptik je podle Fichta s dogmatikem zajedno v otázce, v čem spočívá podstata vědění, a ukazuje pouze, že není možné dosáhnout poznání, které by stanoveným kritériím mohlo dostát, nebot' v dané koncepci stojí prubířský kámen pravdivosti vět mimo dosah poznávajícího subjektu. ${ }^{50}$ Fichte naopak dochází k závěru, že se oba pletou v odpovědi na otázku, v čem vůbec spočívá podstata našeho poznání, a předkládá proto jinou koncepci. Čtvrtá námitka vůči dogmatikovi zní, že se dopouští performativního rozporu, když volí jako východisko věc o sobě, nebot' aby mohl věc jako svůj princip pojmout, musí abstrahovat od Já, k čemuž je ovšem vždy třeba právě abstrahujícího Já. ${ }^{51}$

Již jsme poznamenali, že z Fichtova odmítnutí realistického dogmatismu nemůžeme usoudit na jeho neproblematické přitakání idealismu. Chceme-li idealismu vědosloví porozumět, musíme obrátit pozornost $\mathrm{k}$ Základu, jenž je pro pochopení idealismu z několika důvodů zásadní. Když totiž Fichte za prvé ve složitém sledu myšlenkových kroků analyzuje třetí zásadu, kterou je třeba pokládat za první hrubou syntézu prvních dvou zásad, formuluje v reakci na odhalené rozpory další syntézy, jimž odpovídají různé druhy realismů a idealismů. Během tohoto postupu Fichte ukazuje, které formy realismu a idealismu nezastává, stejně jako důvody, proč je jako nedostatečné zavrhuje. Fichte tak postupně

\footnotetext{
48 Srv. J. G. Fichte, $D U ́$, str. 94.

49 Srv. J. G. Fichte, $E E$ ( $F W$ I, str. 437 n.).

50 Srv. J. G. Fichte, Vorlesungen (GA IV,1, str. 213).

51 Srv. J. G. Fichte, Recension (FW I, str. 19); SL (FW IV, str. 30); WLnmK (GA IV,2, str. 56).
} 
odmítá kvalitativní, kvantitativní a další podoby realismu i idealismu. Za druhé pak formuluje finální syntézu vyjadřující jeho vlastní pozici a v souvislosti s ní předkládá a objasňuje některé stěžejní pojmy, jejichž výklad je pro pochopení idealismu vědosloví zásadní. K těmto termínům náleží kromě usilování a obrazotvornosti především náraz a věc o sobě. Jelikož z hlediska našeho cíle není nutné, abychom sledovali celý sled Fichtových kroků v Základu, zaměříme se přímo na výsledek, $\mathrm{k}$ němuž dospívá, a na jeho uchopení uvedených klíčových konceptů.

V souvislosti s nárazem je třeba poznamenat, že tento termín musíme chápat figurativně a že slovo „Anstoß“ v současné němčině stejně jako v němčině konce 18 . století neoznačuje pouze náraz, ale také podnět nebo impuls. ${ }^{52}$ Náraz nesmíme chápat jako kauzální mechanický střet dvou předem se vyskytujících jsoucen, nýbrž jako vyjádření neodvoditelné skutečnosti, že Já z nějakého důvodu nemůže pokračovat ve své činnosti dále a cítí se být zadrženo, v důsledku čehož si vytváŕí představu na sobě nezávislé reality podléhající zákonům, jež jsou odrazem zákonů inherentních konečné rozumové bytosti. ${ }^{53}$ Fichte tutéž souvislost ve vědosloví podaném novou metodou označuje zřejmě vhodněji pomocí termínu ,původní omezenost“. 54 Náraz můžeme vyložit jako nejabstraktnější možnou podobu něčeho nezávislého na Já, k níž Fichte dospívá poté, co jako neudržitelné vykázal koncepce předložené kvalitativním a kvantitativním realismem. ${ }^{55}$ Jedním z jeho klíčových aspektů je, že je co do své fakticity nepřevoditelný na činnost Já. Jakkoli Já náraz připisuje Ne-Já, ve skutečnosti je spíše Ne-Já produktem činnosti Já, které Já klade v reakci na náraz jako vysvětlující důvod svého omezení. I když ovšem filosofie může dovodit, že náraz tvoří transcendentální podmínku předmětného vědomí a že k němu musí docházet, pokud je máme moci vysvětlit, nemůže podle Fichta objasnit jeho aktuální výskyt.

Pokud si má být Já v souvislosti s nárazem vědomo svého omezení, nemůže být pouze konečné, nýbrž musí svou omezenou činnost odměřit

52 Tuto tezi dokládá několik Fichtových obratů. Srv. např. $Z V V$, str. 107.

53 Srv. např. G. Zöller, German Realism. The Self-Limitation of Idealist Thinking in Fichte, Schelling, and Schopenhauer, in: K. Ameriks (vyd.), The Cambridge Companion to German Idealism, Cambridge 2000, str. 204.

54 Srv. J. G. Fichte, $W \operatorname{LnmK}(G A$ IV,2, str. 68).

55 K pojmu nárazu dále srv. A. K. Soller, Fichtes Lehre vom Anstoß, Nicht-Ich und Ding an sich in der GWL. Eine kritische Erörterung, in: W. H. Schrader (vyd.), Fichte Studien, 10, Amsterdam - Atlanta 1997, str. 175-189; H. Eidam, Fichtes Anstoß. Anmerkungen zu einem Begriff der Wissenschaftslehre von 1794, in: tamt., str. 191-208. 
na totalitě činnosti Já, ${ }^{56}$ a musí proto být současně konečné i nekonečné, což znamená, že jeho činnost nesmí být nárazem odražena zcela, že musí usilovat o překročení hranice a klást se za tuto hranici jako nekladoucí sebe sama. Skutečné vědomé Já je konečné Já, které klade proti sobě Ne-Já a současně klade sebe sama jako nekonečné do oblasti toho, co být má. Je tedy vnitřně rozděleným Já, pro něž je charakteristické dynamické napětí mezi konečností a nekonečností odhalující se konkrétnímu Já ve vědomí kategorického imperativu neboli apelu na autonomii a sebeurčení. Absolutní Já nabývá v tomto kontextu podoby ideálu, jenž je v lidském rozumu nutně př́itomen a $\mathrm{k}$ němuž se lze nekonečně přibližovat, aniž by bylo možné jej dosáhnout.

Je třeba zdůraznit, že kladení hranice není důsledkem „rozhodnutí“ Já, ale nemožnosti realizovat nekonečné sebekladení, jež má svi̊j důvod v něčem, co z Já z hlediska fakticity nelze odvodit, a co je potud nejáské. ${ }^{77}$ Jakkoli je však tento realistický element u Fichta př́tomen, neznamená krok mimo pole kritického idealismu, nebot' je doplněn o idealistickou perspektivu vědosloví coby „realidealismu“ či ,idealrealismu“. Jakožto realidealismus poukazuje vědosloví při výkladu zkušenosti k něčemu, co nelze převést na činnost Já, avšak jakožto idealrealismus současně v idealistickém duchu zdůrazňuje, že se toto něco nachází mimo okruh možného poznání a že příslušná myšlenka není ničím jiným než produktem filosofické reflexe, jejíž průběh je určen zákony myšlení konečného rozumu. S touto poznámkou se dostáváme $\mathrm{k}$ nutnému kruhu, $\mathrm{z}$ něhož konečný duch nemůže vystoupit, a současně také k porozumění způsobu, jak Fichte chápe pojem věci o sobě.

Fichte sám $\mathrm{k}$ tomuto problému přiléhavě poznamenává, že s uchopením věci o sobě se to má jako se snahou pojmout v mysli nekonečný prostor. Jakmile ho uchopujeme, činíme ho nutně konečným, jakkoli ho zamýšlíme pojmout jako nekonečný. ${ }^{58}$ Věc o sobě nám rovněž „,protéká mezi prsty“, nebot' když ji klademe jako nezávislou, klademe ji jako nezávislou. Jedná se o neuchopitelný pojem, jenž „,v̌̌ak přesto jako předmět nutné ideje musí být položen do základu veškerého našeho filosofování“. 59

56 Srv. J. G. Fichte, $Z V V$, str. 111.

57 Já tedy nevytváří své omezení samo, jak se můžeme dočíst v řadě starších výkladů, podle nichž Já omezuje sebe sama např. proto, aby si vytvořilo svět jako jakousi „morální tělocvičnu“ pro své mravní jednání.

58 Srv. J. G. Fichte, WLnmK (GA IV,2, str. 68). Dále srv. W. Janke, Fichte. Sein und Reflexion - Grundlagen der kritischen Vernunft, Berlin 1970, str. 185.

59 J. G. Fichte, $Z V V$, str. 162. 
Podvojná povaha nárazu a věci o sobě přitom odráží podvojnou strukturu Já samého. Zatímco pro praktické Já jsou náraz a věci skutečné a nezávislé, z hlediska teoretického Já jsou naopak něčím pouze ideálním. Stejně jako se však praktické a teoretické Já navzájem podmiňují, nebot' chtění podmiňuje poznávání a poznávání chtění, podmiňují se také obě dimenze věci o sobě a nárazu: náraz je reálný, jen pokud je ideální, a je ideální, jen pokud je reálný. ${ }^{60}$ Fichte $\mathrm{v}$ důležité části Základu odlišuje svou pozici od dogmatického idealismu i realismu a shrnuje ji následovně:

„to, že konečný duch musí nutně klást něco absolutního mimo sebe (věc o sobě), a přesto musí na druhé straně uznat, že toto absolutní existuje pouze pro něj (že je nutným noumenon), je kruhem, jejž může tento duch rozšiřovat do nekonečna, z nějž však nemůže vystoupit. Systém, který na takovýto kruh vůbec nebere ohled, je dogmatickým idealismem, nebot' pouze tento kruh nás ohraničuje a činí konečnými bytostmi. Systém, který si namlouvá, že z něj vystupuje, je transcendentním realistickým dogmatismem. “61

Náraz a věc o sobě jsou tak pro Fichta negativní hraniční koncepty, u nichž končí veškeré naše poznání. Hraniční charakter věci o sobě Fichte vyjadřuje např. v dopisu Mehmelovi:

„věta vědosloví Es gibt kein Ding an sich vůbec není, řečeno s Kantem, zápornou, nýbrž nekonečnou větou, která pouze ř́ká, že zde je naše poznání zcela u konce a že za onu hranici nemůžeme v našem myšlení bez zjevného rozporu vykročit ani pozitivně nebo negativně dogmaticky, ani skepticky." ${ }^{\circ 2}$

60 Srv. D. Breazeale, The Spirit of the Wissenschaftslehre, in: S. Sedgwick (vyd.), The Reception of Kant's Critical Philosophy. Fichte, Schelling, and Hegel, Cambridge 2000, str. 177. Dále k tomuto bodu a obecně realismu a idealismu u Fichta srv. V. Pluder, Die Vermittlung von Idealismus und Realismus in der Klassischen Deutschen Philosophie. Eine Studie zu Jacobi, Kant, Fichte, Schelling und Hegel, Stuttgart-Bad Cannstatt 2013, str. 238.

61 J. G. Fichte, $Z V V$, str. 161.

62 Srv. dopis Mehmelovi z 22. 11. 1800. Přeložil L. K. 
Naše poznání končí u faktu, že dochází k nárazu, že jsme omezeni a že dochází k protikladení. Kdo tuto hranici překračuje, vydává se nutně na scestí dogmatismu, který může být jak idealistický, tak realistický: ${ }^{63}$

„V našem tázání můžeme jít nad zkušenost, a to se také děje; avšak nad filosofii v našem tázání rozumně jít nemůžeme - ptát se například, co je o sobě důvodem omezenosti, odporuje samo sobě a je $a b$ surdní. Jednalo by se o použití rozumu, při němž by se abstrahovalo od veškerého rozumu." 64

„Kdybychom se ptali, čím je ono omezující, byli bychom transcendentní. Jsem omezen je tím posledním.“"65

„Kritický idealismus vznik matérie vysvětluje z absolutního omezení a ukazuje, že je nesmysl ptát se dále po důvodu tohoto omezení." “66

Jinak řečeno, u původní omezenosti je „rozum u konce“. ${ }^{67}$ Toto stanovisko je koncizně vyjádřeno také ve Druhém úvodu:

„Nepřijímáme tedy $\mathrm{k}$ vysvětlení poznání vůbec žádný dotek, vůbec žádnou afekci? Abych tento rozdíl pojal jedním slovem: Ovšemže vychází veškeré naše poznání $z$ nějaké afekce, avšak nikoli z afekce předmětem." 68

Fichte touto větou nechce říci, jak je patrné z předchozího, že absolutní Já bez dalšího afikuje sebe sama (pak by bylo vědosloví transcendentní) nebo že spontánně vytváŕí nahodilé obsahy zkušenosti, ale že afekci v rámci kritické transcendentální filosofie nelze dále vysvětlit. Znakem dogmatické filosofie je, že vychází z existence něčeho, co údajně existuje

63 K věci o sobě u Fichta srv. dále R. Schäfer, Die Gigantomachie von Idealismus und Realismus in der Frühphilosophie Fichtes und Schellings, in: M. GerhardA. Sell - L. De Vos (vyd.), Metaphysik und Metaphysikkritik in der Klassischen Deutschen Philosophie, Hamburg 2012, str. 83-114.

64 J. G. Fichte, $W \operatorname{LnmK}(G A$ IV,2, str. 26). Přeložil L. K.

65 J. G. Fichte, Vorlesungen (GA IV,I, str. 212). Přeložil L. K.

66 J. G. Fichte, Platner (GA II,4, str. 249). Přeložil L. K.

67 Srv. text z Wissenschaftslehre nova methodo (GA IV,2, str. 124). Přeložil L. K.

68 J. G. Fichte, $D U ́$, str. 86. 
nezávisle na čistém vědomí konečného subjektu a má explanační roli ve vysvětlení zkušenosti. Je přitom lhostejné, zda je tato předpokládaná entita duchovní nebo materiální povahy. Zásadním aspektem vědosloví naopak je, že si naprosto „netroufá říci, jak jsou věci o sobě, tzn. nezávisle na rozumové bytosti, protože ví, že tato otázka a toto tvrzení jsou beze smyslu, nýbrž jak nutně musí být pro nás, pro možné Já“ .69 Vědosloví je jinak řečeno kritickou transcendentální filosofií, která má za cíl identifikovat otázky „beze smyslu“ a vytyčit hranice možného poznání. ${ }^{70}$

Ve vztahu k otázce realismu a idealismu vědosloví můžeme shrnout, že nakolik spočívá podstata realismu $\mathrm{v}$ připuštění existence něčeho nezávislého na Já, natolik můžeme Fichta legitimně označit za realistu, nebot' idealismus vědosloví má svou hranici v nárazu, jenž je co do své fakticity na Já nepřevoditelný. Fichtův realismus je nicméně na druhé straně jasně omezen a kvalifikován kritickou povahou vědosloví, nebot' Fichte rozhodně nehodlá s nárokem na poznání tvrdit, že existuje na Já nezávislý svět věcí o sobě, které kauzálně působí na Já a generují nahodilé obsahy zkušenosti. Idealistická explikace předmětného vědomí vycházející z čistého Já se nutně dostává do bodu, v němž musí uznat existenci něčeho nezávislého na Já (realismus), avšak současně si uvědomuje, že ji připouští pouze na základě zákonů rozumové reflexe této zkušenosti (idealismus). Bylo by proto mimochodem zavádějící tvrdit, že Fichte odmítá věc o sobě. Spíše se ji snaží zasadit do náležitě rozpracovaného kritického systému, vysvětlit její status a genezi, a tím eliminovat dogmatický prvek kontaminující Kantův kritický projekt nebo lépe řečeno filosofii kantiánů. Věc o sobě je pro něj nutným produktem reflexe, který Já podle zákonů myšlení vytváŕí v reakci na konfrontaci se svou omezeností.

Vědosloví tak nakonec dospívá do výše zmíněného kruhu, který je podle Fichta nevyhnutelný a nepřekročitelný. Není ani „materialistickéc, nebot' nevychází z věci o sobě, ani „idealistické“, protože nevychází z ducha jako substance, ani „dualistické“, poněvadž nevychází z ducha a věcí o sobě jako oddělených substancí. ${ }^{71}$ Jakožto transcendentálně kritický projekt spíše předvádí nedostatky různých teoretických pozic a ukazuje, že dokonce i sofistikovaná střední cesta mezi nimi nalezená

69 J. G. Fichte, Platner (GA II,4, str. 72). Přeložil L. K.

70 Srv. tamt., str. 249.

71 Srv. J. G. Fichte, $W \operatorname{Lnm} K(G A$ IV,2, str. 55). 
vědoslovím, která dokáže vyřešit nejvíce identifikovaných rozporů, čelí hranicím, jež konečný lidský rozum principiálně nemůže překročit.

Na závěr doplňme ještě jednu důležitou tezi, jež s problematikou realismu a idealismu úzce souvisí. Podobně jako nelze v kritické filosofii vysvětlit fakticitu původní omezenosti, nýbrž pouze dovodit, že musí docházet $\mathrm{k}$ nárazu, pokud máme moci vysvětlit předmětné vědomí, a ukázat mechanismus, na jehož základě jsme si tohoto omezení vědomi, nelze dále objasnit ani nahodilé obsahy zkušenosti, které rovněž tvoří absolutní hranici našeho poznání:

,jsem původně omezen a je ve mně také původně rozmanitost pocitů; to nemohu změnit, přes to nemohu vykročit, jedná se o podmínku veškerého mého bytí. “72

Fichtovi jde ve vědosloví o explikaci forem a nutných rysů materiální dimenze zkušenosti. Snažit se identifikovat pramen kontingentních obsahů zkušenosti nebo vysvětlit, proč jsou takové, jaké jsou, by znamenalo vstoupit na pole dogmatismu a opustit hranice kritické filosofie. Pestrá rozmanitost pocitů a kontingentních daností jsou podle Fichta neodvoditelná, „iracionální“ fakta, která můžeme pouze konstatovat, nikoli však zdůvodnit. ${ }^{73}$ Ve spekulaci nemůžeme vysvětlit, proč je červená červenou nebo proč je určitá osoba mezi všemi rozumovými bytostmi právě touto osobou. ${ }^{74}$ Když Fichte tvrdí, že jsou veškeré obsahy a předměty vědomí produkovány obrazotvorností, nechce tím říci, že obrazotvornost vytváří konkrétní obsahy zkušenosti, nýbrž spíše že produkuje vědomí těchto obsahů, matérii ve smyslu substrátu počitků apod. I když tedy náraz podle Fichta do Já nic nevnášíi ${ }^{75}$ bylo by chybou bez dalšího tvrdit, že jsou nahodilé obsahy ve vědosloví odvozeny z činnosti Já. Jakkoli Fichte na tuto okolnost neklade dostatečný důraz a jakkoli mohou určité odvozené souvislosti a obsahy ve čtenáři budit nesprávná očekávání,

72 J. G. Fichte, $W \operatorname{Lnm} K(G A$ IV,2, str. 68). Přeložil L. K.

73 Srv. T. Rosefeldt, Dinge an sich und der Außenweltskeptizismus. Über ein Missverständnis der frühen Kant-Rezeption, in: D. Edmundts (vyd.), Self, World, and the Art. Metaphysical Topics in Kant and Hegel, Berlin 2013, str. 221-260. Dále srv. Ch. Lotz, Sehnsüchtiges Sein. Anmerkungen zu Fichte und Husserl, in: H. Girndt (vyd.), Fichte Studien, 22, Amsterdam - New York 2003, str. 162.

74 Srv. J. G. Fichte, $D U ́$, str. 86 n. K tomuto tématu srv. dále M. Altman, Fichte's Transcendental Idealism. An Interpretation and Defense, in: týž (vyd.), The Palgrave Handbook of German Idealism, London 2014, str. 337.

75 Srv. J. G. Fichte, $Z V V$, str. 160. 
zastává v konečném důsledku pozici, kterou můžeme závěrem přirovnat k Husserlovu stanovisku, podle něhož je hyletická vrstva vědomí tvořena „protopředměty““, 76 které naprosto nejsou konstituovány činností Já. ${ }^{77}$

\section{ZUSAMMENFASSUNG}

Im Aufsatz wird die frühe Wissenschaftslehre als der „kräftigste Idealismus" (Jacobi) im Sinne vom konsequenten kritischen transzendentalen Idealismus präsentiert. In den Hauptteilen des Textes werden die Methode der Wissenschaftslehre, der Status der in der Wissenschaftslehre dargelegten Handlungen und der Status der Welt, zu der das wirkliche Bewusstsein bezogen ist, untersucht. In diesem Kontext wird das Ding an sich als ein integraler Bestandteil der Wissenschaftslehre und als ein „unbegreiflicher“ Begriff dargestellt, der die notwendigen Grenzen des endlichen Verstandes markiert.

SUMMARY

The paper presents the early Wissenschaftslehre as the "strongest idealism" (Jacobi) in the sense of a consistent critical transcendental idealism. The main parts of the text examine the method of the Wissenschaftslehre and the ontological status of acts described in it, as well as the status of the world to which the real consciousness is related. In this context, the thing-in-itself is presented as an integral part of the Wissenschaftslehre and an "inconceivable" concept, marking the necessary cognitive boundaries of the finite mind.

76 Srv. E. Husserl, Ideje k čisté fenomenologii a fenomenologické filosofii II. Fenomenologická zkoumání o konstituci, přel. E. Kohák aj., Praha 2006, str. 198.

77 Vydání této studie bylo podpořeno Grantovou agenturou České republiky v rámci projektu GA16-11880S ,Duch, prŕíroda a společnost v klasické německé filosofii“ “̌̌ešeného na Univerzitě Karlově v Praze. 